\title{
PENGEMBANGAN MULTIMEDIA INTERAKTIF MENGGUNAKAN ADOBE FLASH CS3 PROFESIONAL UNTUK MENINGKATKAN HASIL BELAJAR IPS SISWA KELAS 4 SD
}

\author{
Lilis Retno Sundari', Suroso ${ }^{2}$, Yustinus ${ }^{3}$ \\ ${ }^{1}$ Pendidikan Guru Sekolah Dasar, Universitas Kristen Satya Wacana Salatiga, lilisretnosundari96@gmail.com \\ ${ }^{2}$ Pendidikan Guru Sekolah Dasar, Universitas Kristen Satya Wacana, suroso.sltg@gmail.com \\ ${ }^{3}$ Pendidikan Guru Sekolah Dasar, Universitas Kristen Satya Wacana, ytinus@staff.uksw.edu
}

INFO ARTIKEL

Riwayat Artikel:

Diterima: 23-03-2018

Disetujui: 06-04-2018

Kata Kunci:

Pengembangan, Multimedia, Adobe Flash CS3 Profesional, Hasil Belajar IPS

\section{ABSTRAK}

Abstrak:: Penelitian ini bertujuan 1)mengembangkan multimedia interaktif menggunakan Adobe Flash CS3 Profesional untuk meningkatkan hasil belajar IPS Kelas 4 SD. 2) pengembangan multimedia interaktif menggunakan Adobe Flash CS3 Profesional dapat meningkatkan hasil belajar IPS Kelas 4 SD. Penelitian ini menggunakan jenis penelitian pengembangan dengan Model pengembangan ASSURE. Hasil validasi pakar materi $70 \%$ (tinggi) dan validasi pakar media 92\% (sanggat tinggi). Kemudian Rata-rata nilai tahun 2017 dan tahun 2018 mengalami kenaikan 74 menjadi 81. Hasil uji T diperoleh taraf signifikansi a 0,017 . Berdasarkan perolehan hasil belajar siswa setelah menggunakan multimedia interaktif lebih tinggi dari sebelum menggunakan multimedia interaktif.

\begin{abstract}
Abstrak:: This study aims to 1) develop interactive multimedia using Adobe Flash CS3 Professional to improve learning outcomes IPS Class 4 SD. 2) development of interactive multimedia using Adobe Flash CS3 Professional can improve learning result of IPS Class 4 SD. This study uses a type of development research with ASSURE development model. Expert material 70\% (high) material validation and media experts validation 92\% (high conformity). Then the average value of 2017 and 2018 increased 74 to 81 . T test results obtained significance level a 0.017. Based on the acquisition of student learning outcomes after using interactive multimedia is higher than before using interactive multimedia.
\end{abstract}

\section{A. LATAR BELAKANG}

Perkembangan teknologi semakin hari menunjukkan kemajuan. Kehadirannya telah memberikan dampak yang cukup besar terhadap kehidupan umat manusia dalam berbagai aspek kehidupan. Salah satunya dalam bidang pendidikan. Daryanto dan Karim (2017:1) menyampaikan "pendidikan di abad 21 ditandai dengan pemanfaatan teknologi, informasi dan komunikasi dalam segala segi kehidupan, termasuk dalam proses pembelajaran”. Proses pembelajaran guru bukan hanya sekedar mengajar, melainkan harus menjadi manajer kelas yang mampu menciptakan kondisi belajar yang kreatif, aktif, dan inovatif dengan menggunakan media sebagai perantara. Arsyad (2016:10) mengemukakan "Media pembelajaran adalah segala slesuatu yang dapat digunakan untuk menyampaikan pesan atau informasi dalam proses belajar mengajar sehingga dapat merangsang perhatian dan minat siswa dalam belajar". Arsyad (2016:7) mengemukakan sebagai berikut:

"Teknologi pembelajaran suatu disiplin ilmu tersendiri yang bukan hanya terbatas pada media dalam bentuk peralatan fisik semata, melainkan merupakan kajian dan praktek etis dalam mendesain, mengembangkan, menggunakan, mengelola, dan mengevaluasi proses dan sumber teknologi sesuai untuk memfasilitasi belajar dan memperbaiki kinerja tenaga pendidik, peserta didik dan organisasi pendidikan".

Teknologi yang semakin canggih memudahkan guru dalam menyiapkan proses pembelajaran yang aktif, kreaktif dan inovatif. Oleh karena itu media pembelajaran berbasis IPTEK sangat diperlukan. Pembuatan media pembelajaran saat ini sudah banyak, salah satunya dengan pembelajaran IPS. Materi ini diajarkan mulai dari SD sampai materi tingkat sampai SMP. Menurut Permendiknas No 222006 IPS mempunyai tujuan sebagi berikut:

“1) mengenal konsep-konsep yang berkaitan dengan kehidupan masyarakat dan lingkungan. 2) memiliki kemampuan dasar untuk berpikir logis dan kritis, rasa ingin tahu, memecahkan masalah, dan keterampilan dalam kehidupan sosial. 3) memiliki komitmen dan kesadaran terhadap nilai-nilai sosial dan kemanusian. 4) memiliki kemampuan berkomunikasi, 
berkerjasama dan berkompetensi dalam masyarakat majemuk, di tingkat lokal, nasional, dan global”. (Depdiknas, 2006).

Dalam rangka mencapai tujuan pembelajaran IPS maka guru berupaya untuk meningkatkan kompetensinya melalui pembelajaran di kelas. Akan tetapi permasalahan yang sering dihadapi siswa yang satu dengan siswa yang lain yaitu memiliki gaya belajar yang berbeda-beda. Ada siswa yang lebih paham dalam belajar dengan teks, suara, gambar, video dan lain-lain. Perkembangan IPTEK dalam pendidikan salah satu bentuk aplikasi komputer yang dapat digunakan dalam pembelajaran adalah multimedia. Arsyad (2016:163) menyatakan "multimedia adalah berbagai macam kombinasi grafik, teks, suara, video, animasi dan lainlain, yang bertujuan untuk menyajikan informasi dalam bentuk yang menyenangkan, menarik, mudah dimengerti, dan jelas”.

Berdasarkan studi dokumen, hasil observasi dan wawancara di kelas 4 SDN 1 Kembang Kuning pada pembelajaran IPS menunjukkan: (1) siswa masih kesulitan dalam menerima materi pembelajaran. (2) siswa cenderung pasif dalam proses pembelajaran, dan siswa mengalami rasa malu dalam hal bertanya. (3) buku cetak siswa kurang memberikan materi secara lebih menarik dan lebih khusus tentang lingkungan siswa. (4) guru belum memanfaatkan IPTEK dalam membuat media pembelajaran. (5) Perhatian siswa belum sepenuhnya fokus pembelajaran, sehingga hasil belajar IPS masih rendah.

Berdasarkan 5 masalah yang di atas peneliti hanya fokus pada masalah, 1) Buku cetak siswa kurang memberikan materi secara lebih menarik dan lebih khusus tentang lingkungan siswa, 2) Masih banyak guru yang belum memanfaatkan IPTEK dalam membuat media pembelajaran, dan 3) Perhatian siswa belum sepenuhnya fokus pada pembelajaran, sehingga hasil belajar IPS masih rendah.

Permasalahan-permasalahan di atas menunjukkan bahwa pembelajaran saat ini belum dikatakan efektif dan efisien. Sebaiknya guru menggunakan pembelajaran inovatif dan berbantuan multimedia interaktif, sebagai alat bantu guru untuk meningkatkan kemampuan belajar yang lebih mudah, aktif, dan menyenangkan. Agar hasil belajar siswa efektif dalam pencapaian tujuan pembelajaran.

Berpijak pada kesenjangan dan kebutuhan di atas, maka peneliti mengurangi kesenjangan dan menjawab kebutuhan dengan membuat produk pengembangan multimedia interaktif. Dilihat dari studi dokumen nilai siswa kelas 4 SDN 1 Kembang Kuning pada tahunketahun kemampuan anak relatif sama. Pada pontensi hasil belajar IPS semester 1 tahun 2017 rata-rata 76 dan potensi hasil belajar IPS semester 1 tahun 2018 rata-rata 78. Dibuktikan dengan uji normalitas shapiro wilk hasil nilai signifikansi sebesar $\alpha 0,411$ dan $\alpha 0,249>\alpha 0,05$. Hal ini dapat diartikan bahwa penyebaran datanya adalah normal. Selanjutnya uji homogen potensi hasil belajar tahun 2017 dan tahun 2018 memiliki nilai signifikansi sebesar $\alpha 0,386>\alpha$ 0,05. Hal ini dapat diartikan bahwa varian adalah homogen. Selain uji normalitas dan homogen selanjutnya uji $\mathrm{T}$, potensi hasil belajar tahun 2017 dan tahun 2018 dalam uji T memiliki taraf signifikansi atau sig.(2-tailed) sebesar a 0,392 dan $\alpha$ 0,396. Oleh karena $\alpha$ 0,392 > a 0,05 dan $\alpha$ 0,396 > $a$ o,05, maka tidak terdapat perbedaan yang signifikansi antara potensi hasil belajar IPS pada tahuan 2017 dan tahun 2018, dengan kata lain potensi hasil belajar IPS pada tahuan 2017 dan tahun 2018 memiliki kemampuan yang sama.

Pada semester 2 tahun 2017 pada KD Perkembangan teknologi, produksi, komunikasi dan transportasi beserta pengalaman penggunaan diperoleh hasil belajar IPS rata-rata 74. Perlakuan siswa di tahun 2017 tidak menggunakan media pembelajaran multimedia interaktif, maka peneliti akan melihat perbedaan hasil belajar IPS pada KD perkembangan teknologi, produksi, komunikasi dan transportasi beserta pengalaman penggunaan dengan memakai media pembelajaran yang telah dikembangkan peneliti yaitu multimedia interaktif. Pembelajaran berbantuan multimedia interaktif mampu untuk menumbuhkan motivasi siswa dalam belajar, karena multimedia disajikan secara menarik sehingga kegiatan belajar mengajar menjadi lebih menyenangkan. Penggunaan multimedia interaktif juga bisa mengakomodasikan perbedaan siswa dalam menerima materi pembelajaran, sehingga hasil belajar IPS siswa diharapkan mencapai KKM dan lebih tinggi dari sebelum menggunakan multimedia interaktif.

Pembuatan multimedia interaktif mempunyai banyak software yang bisa digunakan dalam sistem komputer anatara lain Miscrosoft Powerpoint, Microflash, Adobe Flash CS3 Profesional, Adobe Photoshop $\mathrm{CS}_{3}$, CorelDRAW $\mathrm{X}_{4}$ dan lain-lain. Dalam penelitian ini memilih menggunakan software Adobe Flash CS3 Profesional, program ini dapat membuat media pembelajaran berbasis teknologi multimedia komputer. Kemampuan program Adobe Flash $\mathrm{CS}_{3}$ Profesional bisa untuk membuat animasi atau aplikasi yang bukan berbasis internet (offline). Dengan Actionscript yang dibawanya, Salah satu program yang bisa digunakan dengan Adobe Flash CS3 Profesional untuk membuat game atau bahan ajar interaktif.

Multimedia interaktif diharapkan dapat membantu siswa dalam memahami materi pembelajaran khususnya materi IPS. Multimedia interaktif merupakan sebuah media pembelajaran interaktif yang terdapat menu awal berupa (SK, KD dan Indikator), materi, gambar, video dan soal evaluasi. Multimedia interaktif ini menvisualkan buku cetak ke dalam multimedia yang mencakup pengetahuan siswa secara luas serta menambahkan kegiatan produksi yang dilakukan masyarakat di lingkungan tempat tinggal siswa, menggunakan software Adobe Flash CS3 Profesional. 
Multimedia interaktif dapat membantu untuk memahami materi produksi, komunikasi dan transportasi serta penggunaan multimedia interaktif sebagai pengalaman dalam penggunaan alat komunikasi modern.

Berdasarkan masalah di atas dapat dirumuskan masalah sebagai berikut sebagai berikut sebagai berikut: 1) Bagaimana pengembangan multimedia interaktif menggunkan Adobe Flash CS3 Profesional untuk meningkatkan hasil belajar IPS siswa kelas 4 SD?. 2) Apakah pengembangan multimedia interaktif menggunakan Adobe Flash CS3 Profesional dapat meningkatkan hasil belajar IPS siswa kelas 4 SD?.

Berdasasarkan permasalahan di atas, penelitian ini bertujuan sebagai berikut: 1) Mengembangkan multimedia interaktif menggunakan Adobe Flash $\mathrm{CS}_{3}$ Profesional untuk meningkatkan hasil belajar IPS siswa kelas 4 SD. 2) Pengembangan multimedia interaktif menggunakan Adobe Flash $\mathrm{CS}_{3}$ Profesional dapat meningkatkan hasil belajar IPS siswa kelas 4 SD.

\section{B. METODE PENELITIAN}

Jenis penelitian ini adalah Research and Development atau penelitian dan pengembangan. Menurut Sukmadinata (2015:164-165) penelitian dan pengembangan atau R\&D merupakan suatu proses atau langkah - langkah untuk mengembangkan suatu produk baru atau penyempurnaan produk yang telah ada, yang dapat dipertanggung jawabkan. Produk tersebut tidak selalu berbentuk perangkat keras (hardware) melainkan juga berbentuk perangkat lunak (software), seperti program komputer pengolahan data, pembelajaran dikelas atau model-model pembelajaran. Penelitian yang dilakukan untuk menghasilkan sebuah produk yaitu multimedia interaktif berupa materi, gambar, soal latihan dan video dengan memanfaatkan software Adobe Flash CS3 Profesional pada mata pelajaran IPS siswa kelas 4 SD. Subjek dalam pelaksanaan penelitian ini adalah 29 siswa kelas 4 SDN 1 Kembang Kuning, Cepogo, Boyolali yang sedang mempelajari materi perkembangan teknologi produksi, komunikasi dan transportasi. Sekolah ini merupakan sekolah yang masih menggunakan KTSP dalam proses pembelajarannya.

Penelitian ini menggunakan langkah-langkah penelitian dan pengembangan yang dikemukakan Sukmadinata yang telah dimodifikasi oleh Mawardi. Langkah penelitian dan pengembangan menurut Sukmadinata yang dikembangkan oleh Mawardi (2014:93) terdiri dari 3 tahap antara lain studi pendahuluan, desain dan pengembangan produk dan pengujian. Dalam penelitian ini langkah-langkah pengembangan hanya sampai dengan tahap ke-2 yaitu desain dan pengembangan produk dan hanya akan diujikan di lapangan terbatas karena keterbatasannya waktu penelitian serta membutuhkan biaya yang banyak.

Langkah dalam penelitan ini melalui dua tahap yaitu: (1) studi pendahuluan, (2) desain dan pengembangan produk. Pada tahap studi pendahuluan pada penelitian ini melalui wawancara, observasi dan studi dokumen. Tahap selanjutnya yaitu desain dan pengembangan, pada tahap ini peneliti menggunakan model pengembangan ASSURE . Menurut Pribadi (2011: 29) menyatakan "model ASSURE yang dikembangkan oleh Smaldino,dkk terdapat enam langkah yaitu; 1. analyze learner characteristic, 2. state objectives, 3. select, modify, or design material, 4. utilize media and materials, 5. require learner participation, 6. Evaluate.

Analisis data pada produk multimedia interaktif yaitu validasi materi dan media menggunakan teknik deskriptif persentase. Terdapat 10 indikator dari setiap 1 indikator terdapat skor 1-5. Masing-masing butiran indikator yaitu skor ( 1 untuk yang sangat rendah, 2 untuk rendah, 3 untuk cukup, 4 untuk tinggi dan 5 untuk sanggat tinggi). Skor hasil pengukuran dengan menggunakan angket tertutup dari ahli media dan ahli materi dijumlahkan kemudian skor tersebut dipresentase dengan menggunakan rumus:

$$
\begin{array}{ll}
\text { AP }=\frac{\text { Skor Aktual }}{\text { Skor Ideal }} & \text { x 100\% } \\
\text { Keterangan : } & \\
\text { AP } & \text { : Angka Persentase } \\
\text { Skor Aktual } & \text { :Skor yang diberikan oleh } \\
& \text { validator ahli. } \\
\text { Skor Ideal } & \text { : Skor maksimal hasil kali antara } \\
& \text { jumlah item dengan skor } \\
& \text { maksimal masing-masing item. }
\end{array}
$$

TABEL 1

Rentang Skor Aspek

Validasi Ahli Materi dan Ahli Media

\begin{tabular}{cc}
\hline Skor & Kriteria \\
\hline $81-100 \%$ & Sangat Tinggi \\
$61-80 \%$ & Tinggi \\
$41-60 \%$ & Cukup \\
$21-40 \%$ & Rendah \\
$1-20 \%$ & Sangat Rendah \\
\hline
\end{tabular}

Berdasarkan Tabel 1 diketahui bahwa validasi ahli materi dan media produk pengembangan multimedia interaktif menggunakan Adobe Flash $\mathrm{CS}_{3}$ Profesional dapat dikatakan layak digunakan apabila angka rata-rata persentase mencapai minimal $\geq 61 \%$ (Mawardi, 2014:113).

Sedangkan pada tahap analisis data uji coba terbatas ini menggunakan teknik deskriptif kuantitatif, kualitatif dan uji beda. Teknik uji beda rata-rata hasil belajar siswa dilakukan dengan menggunakan teknik parametik uji independent sample T-test yaitu dengan menghitung perbedaan rata-rata hasil belajar IPS tahun 2017 dan tahun 2018. Sedangkan untuk respon guru, respon siswa dan observasi menggunakan teknik diskripsi dan presentase. 


\section{B. HASIL DAN PEMBAHASAN}

Pengembangan Multimedia interaktif menggunakan Adobe Flash CS3 Profesional mengacu pada rumusan masalah, yaitu tentang 1) Bagaimana pengembangan Multimedia interaktif menggunakan Adobe Flash CS3 Profesional untuk meningkatkan hasil belajar IPS kelas 4 SD. 2) Apakah pengembangan Multimedia interaktif menggunakan Adobe Flash $\mathrm{CS}_{3}$ Profesional dapat meningkatkan hasil belajar IPS kelas 4 SD. Pengembangan multimedia interaktif melalui 6 langkah yaitu: 1. analyze learner characteristic, 2. state objectives, 3. select, modify, or design material, 4. utilize media and materials, 5. require learner participation, 6. Evaluate.

\section{Langkah Characteristic \\ Analyze Learners}

Langkah pertama yang dilakukan adalah analisis kebutuhan merupakan langkah yang perlu diperhatikan untuk menentukan kemampuankemampuan atau kompetensi yang akan dipelajari oleh siswa dalam meningkatkan efektifitas dan hasil belajar. Langkah ini telah berhasil dilakukan studi dokumen nilai pembelajaran IPS tahun 2017 dan 2018, selain itu wawancara dan observasi kepada wali kelas 4 dan observasi saat pembelajaran IPS. Berdasarkan hasil studi dokumen, wawancara dan observasi diperoleh permasalahan yang berfokus pada 1) Buku cetak siswa kurang memberikan materi secara lebih menarik dan lebih khusus tentang lingkungan siswa, 2) Masih banyak guru yang belum memanfaatkan IPTEK dalam membuat media pembelajaran, dan 3) Perhatian siswa belum sepenuhnya fokus pada pembelajaran, sehingga hasil belajar IPS masih rendah.

\section{Langkah State Objectives}

Langkah kedua yaitu, standar dan tujuan berhasil ditentukan standar kompetensi, kompetensi dasar dan indikator yang akan dikembangkan sebagai produk multimedia dalam penelitian ini yang sudah di sesuaikan dengan kurikulum SDN 1 Kembang Kuning yang masih menggunakan kurikulum KTSP.

Standar kompetensi yang dipilih adalah 2. Mengenal sumber daya alam, kegiatan ekonomi, dan kemajuan teknologi di lingkungan kabupaten/ kota/ dan provinsi. kompetensi dasar adalah 2.3 Mengenal perkembangan teknologi produksi, komunikasi, dan transportasi serta pengalaman menggunakannya dan Indikator adalah 2.3.1 Menyebutkan teknologi produksi pada masa lalu dan masa kini, 2.3.2 Membandingkan jenis-jenis teknologi untuk berproduksi yang digunakan masyarakat pada masa lalu dan masa kini, 2.3.3 Memberikan contoh bahan baku yang dapat diolah menjadi beberapa barang produksi, 2.3.4 Membandingkan kelemahan dan kelebihan teknologi produksi yang digunakan masyarakat masa lalu dan masa kini, 2.3.5
Menyebutkan alat teknologi komunikasi pada masa lalu dan masa kini, 2.3.6 Membandingkan alat-alat teknologi komunikasi yang digunakan masyarakat pada masa lalu dan masa kini, 2.3.7 Menunjukkan cara-cara penggunaan alat teknologi komunikasi masa lalu dan masa kini, 2.3.8 Membandingkan kelemahan dan kelebihan alat komunikasi masa lalu dan masa kini, 2.3.9 Menyebutkan teknologi transportasi pada masa lalu dan masa kini, 2.3.10 Membandingkan jenis-jenis teknologi transportasi pada masa lampau dan masa kini, 2.3.11 Membandingkan kelebihan dan kelemahan alat transportasi masyarakat masa lalu dan masa kini. Pemetaan dan analisis standar kompetensi, kompetensi dasar dan indikator menjadi dasar untuk merancang materi, soal evaluasi dan RPP.

\section{Langkah Select Modify or Desain Method, Media Or Materials}

Langkah ketiga yaitu, telah berhasil ditentukan materi pembelajaran yaitu perkembangan teknologi, Produksi, komunikasi dan transportasi. Sesuai dengan materi maka langkah pengembangan multimedia interaktif, sebagai berikut:.

a. Membuka aplikasi Adobe Flash CS3 Profesional

b. Memilih warna background

c. Membuat layer dan frame baru

d. Membuat tampilan loading

e. Memilih tampilan awal dalam media yang akan digunakan

f. Membuat menu- menu yang terdapat dalam media

g. Memilih dan memasukkan gambar dan animasi ke dalam media

h. Memasukkan materi dalam media

i. Menambahkan shape dalam materi

j. Memasukkan soal dalam menu soal

k. Menentukan skor untuk jawaban yang benar dan jawaban yang salah

1. Memasukkan video dalam media

m. Membuat tombol-tombol dalam media

n. Membuat petunjuk dalam menggunakan media

o. Mendesain tombol dan menu-menu dalam media agar terlihat lebih menarik.

\section{Langkah Tahap Ultilizze Media And Manterials}

Langkah keempat, yaitu telah berhasil dikembangkan produk multimedia interaktif dengan menggunakan Adobe Flash CS3 Profesional dengan pokok bahasan perkembangan teknologi, produksi, komunikasi dan transportasi dengan memanfaatkan teknologi IPTEK salah satunya dengan menggunakan komputer atau laptop . Pada pengembangan produk multimedia interaktif dengan software Adobe Flash CS3 Profesional. Pada tahap ini dapat diketahui kelayakan produk yang 
sudah dikembangkan. Diperoleh validasi materi oleh ahli pakar materi sebesar 70\% dengan kategori tinggi dan diperoleh dari validasi media oleh ahli pakar media sebesar 92\% dengan kategori sangat tinggi. Berdasarkan hasil rata-rata presentase pengembangan multimedia interaktif menggunakan Adobe Flash $\mathrm{CS}_{3}$ Profesional dapat dikatakan layak sebagai media pembelajaran karena angka rata-rata persentase validasi media dan materi $>61 \%$.

Setelah dilakukan uji coba validasi pakar materi dan media dilakukan revisi penyempurnaan multimedia interaktif dari saran pakar materi dan pakar media. Setelah dilakukan revisi sesuai saran makan dilakukan uji coba terbatas . Uji coba terbatas ini dilakukan di SDN 1 Kembang kuning dengan jumlah 29 siswa pada bulan maret 2018. Pada tahap ini juga telah berhasil melakukan proses pembelajaran yang berlangsung menggunakan produk multimedia interaktif yang sudah dikembangkan dengan peran guru.

\section{a. Menu Awal}

Menu awal merupakan tampilan awal sebelum masuk ke dalam menu utama pada multimedia interaktif. Tampilan menu awal pada gambar 1 berikut:

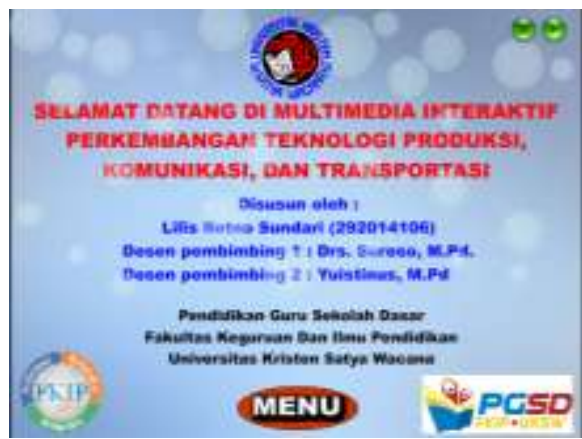

Gambar 1. Tampilan Menu Awal

\section{b.Menu Utama}

Menu utama berikut tentang petunjuk, kompetensi, author, materi, video, evaluasi, dan keluar. Tampilan menu utama dapat dilihat pada gambar 2 berikut:

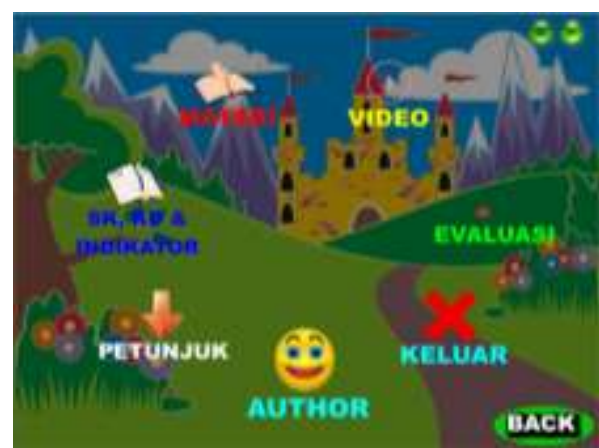

Gambar 2. Tampilan Menu Utama

\section{c. Petunjuk}

Halaman petunjuk berisikan tombol-tombol dan keterangan yang ada dalam multimedia interaktif.
Tampilan petunjuk dapat dilihat pada gambar 3 berikut:

\section{d. Kompetensi}

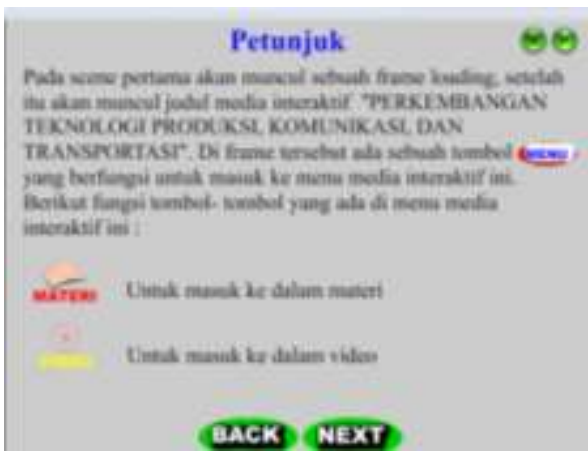

Gambar 3. Tampilan Petunjuk

Halaman kompetensi berisikan tentang standar kompetensi, kompetensi dasar, dan indikator yang ada dalam multimedia interaktif. Tampilan kompetensi dapat dilihat pada gambar 4 berikut:

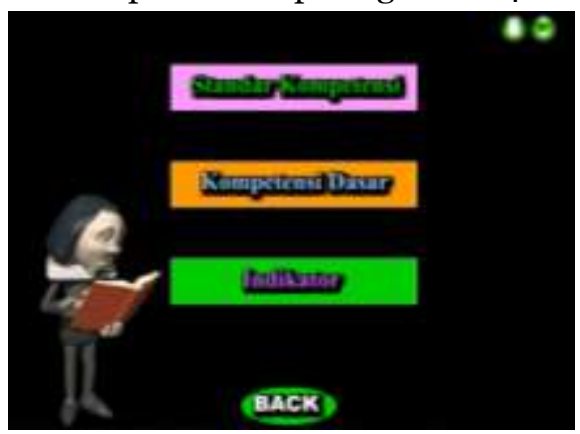

Gambar 4. Tampilan Kompetensi

\section{e. Materi}

Halaman materi berisikan tentang materi produksi, komunikasi dan transportasi yang ada dalam multimedia interaktif. Tampilan halaman materi dapat dilihat pada gambar 5 berikut:

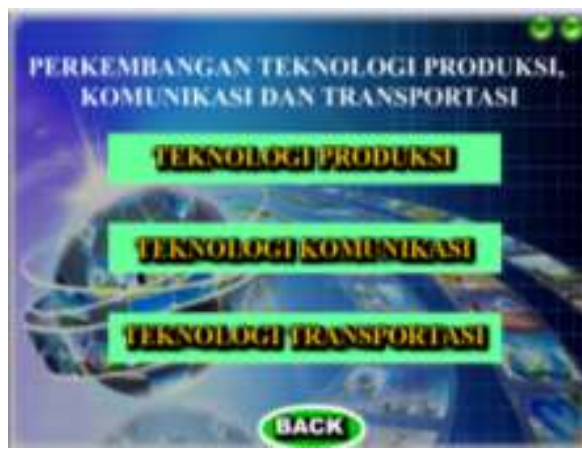

Gambar 5. Tampilan Materi

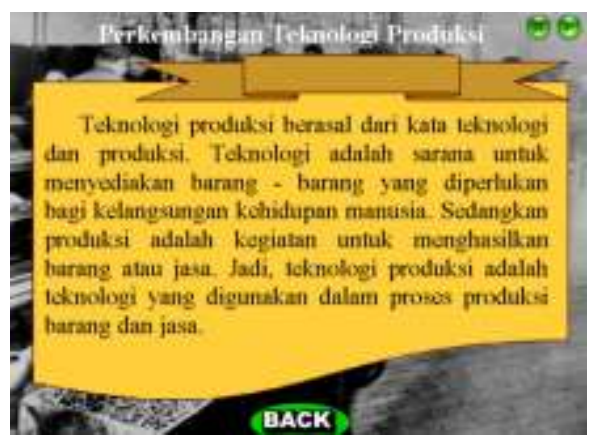

Gambar 6. Tampilan Materi 


\section{f. Video}

Halaman video berisikan tentang video produksi, komunikasi dan transportasi yang ada dalam multimedia interaktif. Tampilan halaman video dapat dilihat pada gambar 7,8, 9 dan 10 berikut:

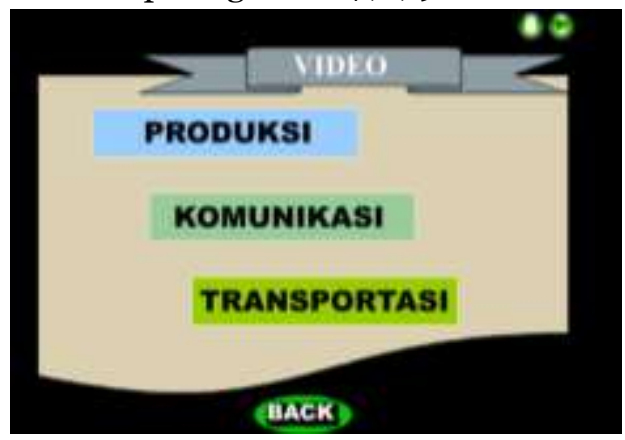

Gambar 7. Tampilan video

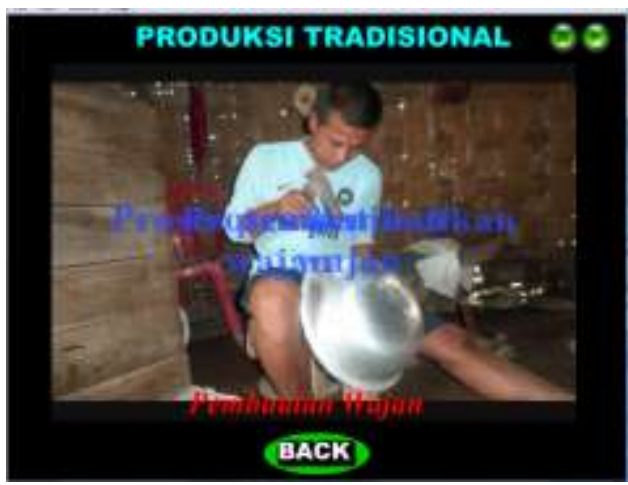

Gambar 8. Tampilan Video

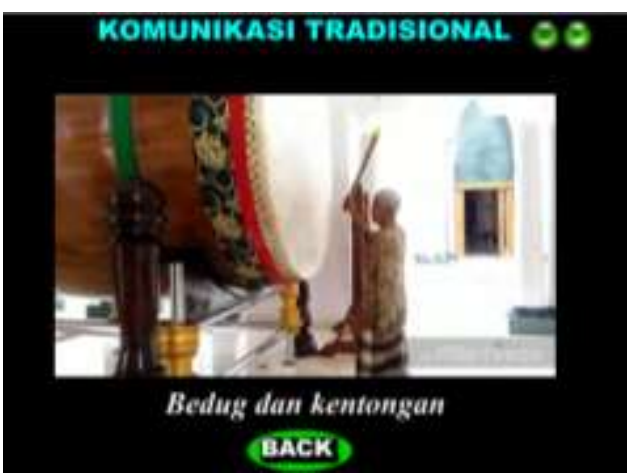

Gambar 9. Tampilan Video

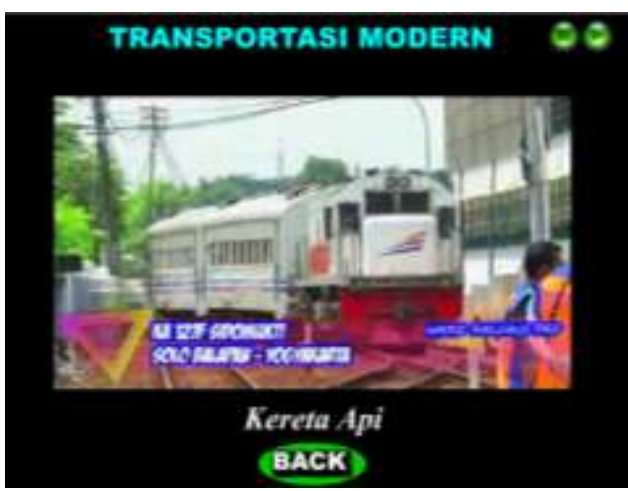

Gambar 1o. Tampilan Video

\section{g. Evaluasi}

Halaman evalusi berisikan tentang latian soal yang akan dikerjakan oleh siswa. Tampilan halaman evaluasi dapat dilihat pada gambar 11 berikut:

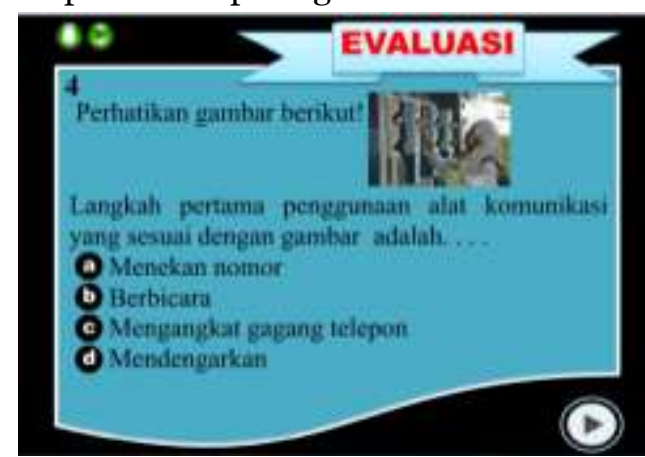

Gambar 11. Tampilan Evaluasi

\section{h. Author}

Halaman berisikan tentang author pengembang yang ada dalam multimedia interaktif. Tampilan halaman author dapat dilihat pada gambar 12 berikut:

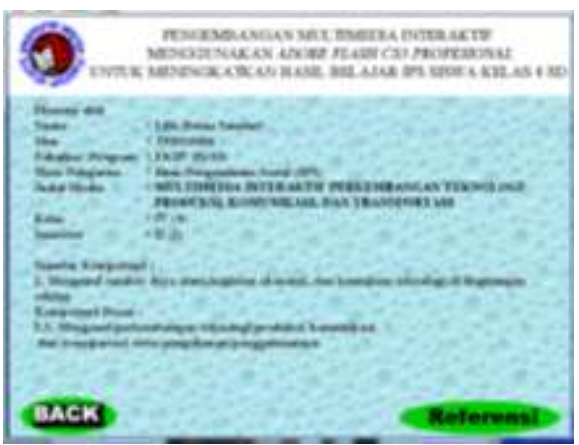

Gambar 12 Tampilan Author

Halaman author terdapat button refrensi (sumber) yang ada dalam multimedia interaktif. Tampilan halaman refrensi dapat dilihat pada gambar 13 berikut:

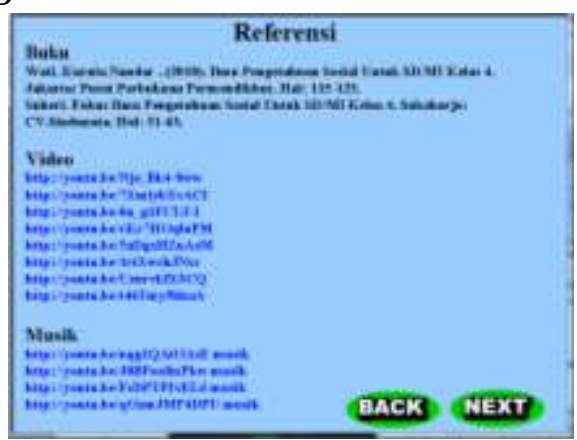

Gambar 13 Tampilan Refrensi

\section{i. Keluar}

Halaman keluar berisikan tentang pilihan keluar atau tidak dalam multimedia interaktif. Tampilan halaman keluar dapat dilihat pada gambar 14 berikut: 


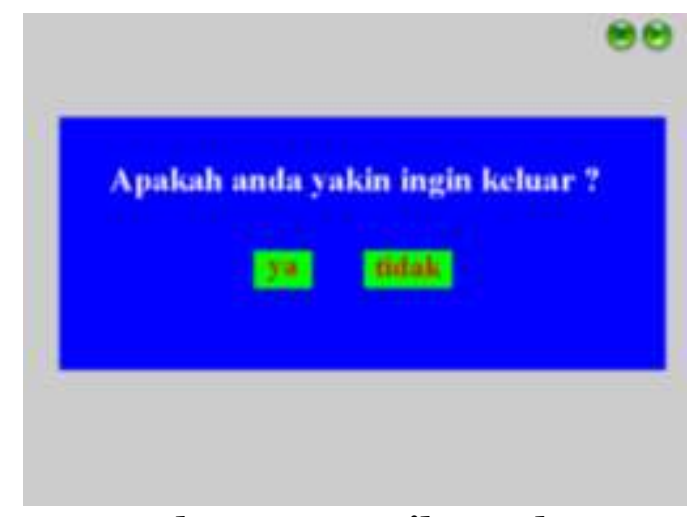

Gambar 14. Tampilan Keluar

\section{Langkah Require Participation \\ Learners}

Langkah kelima, yaitu telah berhasil dilakukan pengembangan multimedia interaktif menggunakan Adobe Flash $\mathrm{CS}_{3}$ Profesional dan melibatkan siswa untuk mengoperasikan produk multimedia interaktif yang sudah dikembangkan.

\section{Langkah Evaluate}

Langkah keenam, yaitu telah berhasil dilakukan uji coba terbatas dengan menggunakan multimedia interaktif untuk mengetahui: Apakah hasil penggunaan multimedia dapat meningkatkan hasil belajar dari pada sebelum menggunakan multimedia interaktif. Dilihat dari potensi hasil belajar tahun 2017 dan tahun 2018 memiliki rata-rata 76 dan 78, dengan uji normalitas shapiro wilk hasil nilai signifikansi sebesar a 0,411 dan a 0,249 > a 0,05. Hal ini dapat diartikan bahwa penyebaran datanya adalah normal. Selanjutnya uji homogen potensi hasil belajar tahun 2017 dan tahun 2018 memiliki nilai signifikansi sebesar $\alpha 0,386>\alpha$ 0,05. Hal ini dapat diartikan bahwa varian adalah homogen. Selanjutnya dilakukan uji $\mathrm{T}$ memiliki taraf signifikansi atau sig.(2-tailed) sebesar $\alpha$ 0,392 dan $\alpha$ 0,396. Oleh karena $\alpha$ 0,392 > a 0,05 dan $\alpha$ 0,396 > $\alpha$ 0,05, maka tidak terdapat perbedaan yang signifikansi antara potensi hasil belajar IPS pada tahuan 2017 dan tahun 2018, dengan kata lain potensi hasil belajar IPS siswa pada tahuan 2017 dan tahun 2018 memiliki kemampuan atau potensi yang sama.

Pada semester 2 tahun 2017 KD tentang Perkembangan Teknologi, produksi, komunikasi dan transportasi berserata pengalaman penggunaan diperoleh hasil belajar IPS rata-rata 74. Perlakuan siswa di tahun 2017 tidak menggunakan media pembelajaran multimedia interaktif, sedangkan pada tahun 2018 tentang KD tersebut siswa diperlakukan menggunakan multimedia interaktif yang telah dikembangkan peneliti dengan memperoleh hasil belajar IPS rata-rata 81 . Sedangkan hasil dari dengan uji normalitas shapiro wilk hasil nilai signifikansi sebesar $\alpha$ 0,164 dan $\alpha 0,319>\alpha$ 0,05. Hal ini dapat diartikan bahwa penyebaran datanya adalah normal. Selanjutnya uji homogen potensi hasil belajar tahun 2017 dan tahun 2018 memiliki nilai signifikansi sebesar a 0,910 > a 0,05. Hal ini dapat diartikan bahwa varian adalah homogen. Berikutnya uji independent sample T-test diperoleh informasi besarnya sigifikansinya dengan memiliki taraf signifikansi sebesar $\alpha$ 0,017. Oleh karena $\alpha$ 0,017 < a 0,05. maka tedapat perbedaan yang signifikansi antara hasil belajar IPS pada tahuan 2017 dan tahun 2018 dengan kata lain terdapat perbedaan hasil belajar IPS yang signifikansi sebelum dan sesudah menggunakan multimedia interaktif. Berdasarkan perolehan tersebut tingkat kompetensi hasil belajar siswa setelah menggunakan multimedia interaktif lebih tinggi atau meningkat dari sebelum menggunakan multimedia interaktif.

Selain itu terdapat saran dan kesan dari guru kelas tentang pendapat multimedia interaktif yaitu multimedia interaktif sudah sesuai dengan materi kelas 4 SDN 1 Kembang Kuning . Materi di dalam multimedia dikemas dengan baik dan menarik. Dalam video pembelajaran khususnya teknologi produksi tradisional sangat menarik karena video menggambarkan proses produksi wajan batik yang ada di lingkungan sekolah dan siswa. Hal itu sangat menarik dalam pembelajaran apalagi ada beberapa keluarga siswa yang masuk dalam video, jadi mereka bisa mengetahui secara nyata proses produksi yang ada di desanya.Proses produksi wajan batik di kupas lagi di dalam materi, bukan hanya sebuah video. Tambah juga alat-alat rumah tangga yang tidak hanya wajan yang diproduksi di lingkungan siswa, sehingga ciri khusus produksi di lingkungan siswa akan lebih bermutu, sehingga produkmu bisa digunakan orang lain dan sekolah-sekolah di luar daerah Kembang Kuning bisa mengetahui proses pembuatan alat-alat rumah tangga yang sudah sampai dibeberapa kota/ kabupaten dan provinsi.

Selanjutnya pendapat dari observer tentang multimedia interaktif yaitu penggunaan multimedia dalam pembelajaran sangat membantu penyampaian materi pada siswa. Siswa sangat antusias dan termotivasi dalam penggunaan multimedia ini, aktifitas siswa lebih banyak dan tidak membosankan dalam proses pembelajaran. Soal evaluasi yang bisa mengetahui nilainya membuat siswa semangat untuk mengerjakannya . Ada yang merasa nilainya belum mencapai targetnya maka diulang-ulang sampai nilainya memuaskan. Karena kekurangan alat dan prasarana, penggunaan multimedia masih dilakukan dengan cara berkelompok. Ada anak yang tidak menyukai teman sekelompoknya, jadi anak tidak terlalu nyaman dengan proses pembelajaran. Tetapi guru berupaya untuk semua anak mencoba mengoperasikan multimedia interaktif. Multimedia interaktif sudah sesuai dengan KD karena tanpa sadar siswa mendapat pengalaman penggunaannya. Otomatis anak-anak sudah berpengalaman menggunakan multimedia interaktif yang dikemas dengan laptop. Laptop merupakan alat 
komunikasi modern. Semoga kedepannya nanti satu anak bisa dengan satu komputer. Selanjutnya angket respon guru, respon siswa dan observasi hasil dari angket respon guru diperoleh 90\%, angket respon siswa diperoleh $97,6 \%$ dan angket observasi diperoleh $87,5 \%$ dengan demikian dapat dikatakan multimedia interaktif dapat diterima dengan baik.

Berdasarkan komponen multimedia interaktif untuk meningkatkan hasil belajar sejalan dengan penelitian Nugraha, R. Gita Ardhy (2017) yang menyatakan keefektifan penggunaan media interaktif berdampak positif terhadap hasil belajar siswa, dilihat dari nilai yang diperoleh siswa yang baik dalam mengerjakan kuis. Penelitian ini juga sejalan dengan penelitian Arda, Sahrul \& Darsikin (2015) yang menemukan multimedia interaktif mendukung peningkatan nilai rata-rata yang diperoleh siswa setelah uji coba sebesar 32,32 dengan gain $<\mathrm{g}>$ sebesar 0,57. Selanjutnya juga sejalan dengan penelitian Sururi, N (2015) yang menemukan perbedaan hasil belajar siswa pada pembelajaran sebelum dan sesudah menggunakan media interaktif. Penelitian Nourmaningrum M.D., dkk (2014) yang menyatakan media interaktif dalam pembelajaran mempunyai pengaruh positif dan signifikansi terhadap hasil belajar siswa. Penelitian juga sejalan dengan temuan Suritmaja, Dwi, dkk (2013) yang menyatakan media pembelajaran multimedia interaktif dapat menarik perhatian siswa dan mampu memberikan semangat serta motivasi kepada siswa untuk belajar sehingga akhirnya meningkatkan prestasi belajar.

Berdasarkan uraian pembahasan uji coba yang dipaparkan di atas dapat di tarik kesimpulan yang utama, yaitu tingkat hasil belajar sesudah menggunakan multimedia interaktif lebih tinggi atau meningkat dari sebelum menggunakan multimedia interaktif yaitu dari 74 menjadi 81 dan hasil uji $\mathrm{T}$ diperoleh taraf signifikansi sebesar $\alpha$ 0,017. Oleh karena $\alpha$ 0,017 < a 0,05, maka tedapat perbedaan yang signifikansi antara hasil belajar IPS pada tahuan 2017 dan tahun 2018 dengan kata lain terdapat perbedaan hasil belajar IPS yang signifikansi sebelum dan sesudah menggunakan multimedia interaktif. Kemudian pendapat guru, observer dan angket respon guru, respon siswa dan observasi dengan persentase respon guru 90\% persentase respon siswa $97,6 \%$ dan persentase observasi $87,5 \%$ dengan demikian dapat dikatakan multimedia interaktif dapat diterima dengan baik

\section{SIMPULAN DAN SARAN}

Berdasarkan hasil penelitian dan pembahasan yang telah dijabarkan sebelumnya, maka didapat simpulan: 1) Produk multimedia interaktif dapat dikembangkan menggunakan desain pengembangan ASSURE (analyze learner characteristic, state objectives, select, modify, or design material, utilize media and materials, require learner participation, Evaluate). 2) Hasil belajar IPS siswa dengan menggunakan multimedia interaktif lebih tinggi atau meningkat dari sebelum menggunakan multimedia interaktif rata-rata nilai tahun 2017 mencapai 74, sedangkan pada rata-rata nilai tahun 2018 mencapai 81. Sedangkan hasil dari uji independent sample T-test diperoleh informasi besarnya sigifikansinya dengan memiliki taraf signifikansi sebesar a 0,017. Oleh karena a 0,017 < a 0,05. maka tedapat perbedaan yang signifikansi antara hasil belajar IPS pada tahuan 2017 dan tahun 2018 dengan kata lain terdapat perbedaan hasil belajar IPS yang signifikansi sebelum dan sesudah menggunakan multimedia interaktif. Berdasarkan perolehan tersebut tingkat hasil belajar siswa setelah menggunakan multimedia interaktif lebih tinggi atau meningkat dari sebelum menggunakan multimedia interaktif.

Berdasarkan penelitian yang sudah dilakukan, maka diberikan saran sebagai berikut: 1) Bagi siswa multimedia interaktif yang dikembangkan memudahkan peserta didik dalam memahami materi perkembangan teknologi produksi, komunikasi dan transportasi. Penggunaan multimedia interaktif dengan komputer atau laptop dikemas sedemikian rupa dapat menambah minat dan motivasi peserta didik dalam belajar IPS. Dengan digunakannya multimedia interaktif peserta didik lebih termotivasi dalam belajar dan membuat siswa lebih aktif. 2) Bagi guru penggunaan multimedia interaktif menjadi salah satu pilihan untuk memilih media dalam pembelajaran. Multimedia interaktif ini dapat membantu guru di dalam proses pembelajaran. 3) Pengembangan yang dilakukan peneliti hanya terbatas pada materi perkembangan teknologi produksi, komunikasi dan transportasi, maka bagi peneliti berikutnya dapat mengembangkan materi yang lain dan lebih luas lagi.

\section{UCAPAN TERIMA KASIH}

Penulis mengucapkan terimakasih kepada dosen pembimbing 1 bapak Dr. Suroso, M.Pd dan pembimbing 2 bapak Yustinus, M.Pd, kepala sekolah dan guru sekolah dasar serta murid kelas 4 SDN 1 Kembang Kuning yang telah membantu dalam menyelesaikan penelitian ini.

\section{DAFTAR RUJUKAN}

[1] Arda, Sahrul Saehana dan Darsikin. 2015. Pengembangan Media Pembelajaran Interaktif Berbasis Komputer untuk Siswa SMP Kelas VIII. E-Jurnal Mitra Sain. Vol 3. No 1

[2] Arsyad, Azhar. 2016. MEDIA PEMBELAJARAN. Jakarta: PT Raja Grafindo Persada

[3] Benny A. Pribadi. 2011. Model ASSURE untuk Mendesain Pembelajaran Sukses. Jakarta: DIAN RAKYAT

[4] Daryanto dan Karim, Syaiful. 2017. PEMBELAJARAN ABAD 21. Yogyakarta: GAVA MEDIA

[5] Depdiknas. 2006. Permendiknas No 22 Tahun 2006 Tentang Standar Isi dan Nomer 23 Tahun 2006 Tentang Standar Kompetensi. Jakarta: Depdiknas 
[6] Mawardi. 2014. Model Desain Pembelajaran Konsep Dasar PKn Berbasis Belajar Mandiri Menggunakan Moodle. Salatiga: Widya Sari Press Salatiga

[7] Nourmaningrum, M. D., Chumdari, \& Hartono. 2014. Pengaruh Penggunaan Multimedia Interaktif Terhadap Hasil Belajar IPA SD. Jurnal Didaktika Dwija Indria. Vol 2. No 4.

[8] Nugroho, R Gita Ardhy. 2017. Pengembangan Media Interaktif Berbasis Adobe Flash CS4 Profesional Pada Pembelajaran Tematik Untuk Siswa Kelas 2 SD. Scholaria. Vol 7. No 2. Hal 94-105

[9] Sukmadinata, Nana Syaodih. 2015. Metode Penelitian Pendidikan. Bandung: Remaja Rosdakarya Offset.

[10] Sururi, N. 2015. Pengembangan Media Pembelajaran Sistem Rangka Manusia Berbasis Multimedia Interaktif di SD Negeri 060876. Medan Timur. Jurnal Tematik. Vol 5. No 1. Hal 49-58.

[11] Suriatmaja, Dwi, dkk. 2013. Pengembangan Multimedia Interaktif Mata Pelajaran TIK Pada Siswa Kelas VIII Semester Ganjil SMP Nengeri 3 Sawan Tahun 2012/2013. Jurnal Edutech Undiksha. Vol 1. No 2

\section{BIODATA PENULIS}

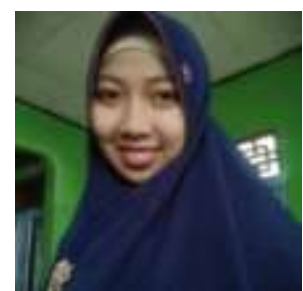

Penulis bernama lengkap "Lilis Retno Sundari". Lahir di Desa Kembang Kuning 03/02 Kecamatan Cepogo, Kabupaten Boyolali, Provinsi Jawa Tengah pada tanggal 22 Februari 1996 dari pasangan Widodo dan Salamah. Penulis adalah anak ketiga dari 4 bersaudara. Pendidikan sekolah dasar dimulai dari SDN 1 Kembang Kuning, SMP Negeri 1 Cepogo, selanjutnya SMA Negeri 1 Cepogo. Selanjutnya melanjutkan pendidikan di Pendidikan Guru Sekolah Dasar Universitas Kristen Satya Wacana Salatiga 2014 sampai sekarang. Saran dan kritik, maupun hal-hal yang berkaitan dengan kelanjutan atau pengembangan dari hasil penelitian ini bisa dikirim ke email penulis: lilisretnosundarig6@gmail.com 